\title{
Risk Factors Associated with Severe Disease in COVID-19
}

\section{COVID-19'da Ciddi Hastalıkla İlişkili Risk Faktörleri}

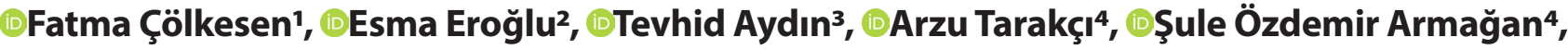 Mihriban Şengöz ${ }^{4}$, $\odot$ Fatma Kacar ${ }^{5}$}

\author{
'Konya Numune Hospital, Department of Infectious Diseases and Clinical Microbiology,Konya, Turkey \\ ${ }^{2}$ Konya Meram State Hospital, Department of Infectious Diseases and Clinical Microbiology, Konya, Turkey \\ ${ }^{3}$ Çumra Community Health Center, Department of Family Medicine, Konya, Turkey \\ ${ }^{4}$ Konya City Hospital, Department of Infectious Diseases and Clinical Microbiology, Konya, Turkey \\ ${ }^{5}$ Konya Medova Hospital, Department of Infectious Diseases and Clinical Microbiology, Konya, Turkey
}

\begin{abstract}
Aim: This study aimed to determine the characteristics and risk factors associated with severe illness from COVID-19.

Material and Method: A total of 186 adult patients (97 female) hospitalized with a diagnosis of COVID-19 (laboratory-confirmed cases, SARS-CoV-2-RNA detected with the molecular method) between March 2020 and May 2020 were included in the study. The possible risk factors evaluated were age, gender, comorbidities, smoking, symptoms, and laboratory parameters at the time of admission to the hospital.
\end{abstract}

Results: A total of 186 patients were included in the final study; 43 (23.1\%) were evaluated as having severe COVID-19 and 143 (76.9\%) as having non-severe COVID-19. Multivariate logistic regression analysis identified risk factors for severe COVID-19 to be age $>65$ years (odds ratio $[\mathrm{OR}]=5.289$, 95\% confidence interval $(\mathrm{Cl}): 1.680$ $16.651, p=0.004)$, elevated levels of lactate dehydrogenase (LDH; $\mathrm{OR}=8.521,95 \% \mathrm{Cl}: 2.445-29.702, \mathrm{p}=0.001)$, ferritin $(\mathrm{OR}=7.436$, 95\% Cl:2.171-25.468, $\mathrm{p}=0.001)$, D-dimer $(\mathrm{OR}=10.076,95 \% \mathrm{Cl}$ : $2.758-36.813, p<0.001)$, creatine kinase myocardial band (CK-MB; $\mathrm{OR}=5.916,95 \% \mathrm{Cl}: 1.833-19.089, \mathrm{p}=0.003)$, and troponin $(\mathrm{OR}=9.201$, 95\% Cl:11.886-44.888, $\mathrm{p}=0.006$ ).

Conclusion: The results of this study examining possible risk factors for severe COVID-19 demonstrated that age $>65$ years and elevated $\mathrm{LDH}$, ferritin, D-dimer, CK-MB, and troponin levels are independent risk factors. Clinicians should consider these potential risk factors for progression to severe illness when treating COVID-19 patients.

Keywords: COVID-19, pandemic, risk factor, severe illness
Öz

Amaç: Çalışmamızın amacı COVID-19'da şiddetli hastalık ile ilişkili özellikler ve risk faktörlerinin belirlenmesidir.

Gereç ve Yöntem: Mart 2020-Mayıs 2020 tarihleri arasında COVID-19 (moleküler yöntemle SARS-CoV-2-RNA tespit edilen olgular) tanısı ile hastaneye yatırılan toplam 186 yetişkin hasta (97 kadın) çalışmaya dahil edildi. Olası risk faktörleri olarak yaş, cinsiyet, komorbidite, sigara kullanımı, semptomlar ve yatış sırasındaki bazı laboratuvar parametreleri irdelendi.

Bulgular: Hastaların 97'si $(\% 52,2)$ kadın olup, 43 (\%23,1) olgu şiddetli COVID-19 ve $143(\% 76,9)$ olgu şiddetli olmayan COVID-19 olarak değerlendirildi. Çoklu değişkenli lojistik regresyon analizinde; 65 yaş üzeri (odds oranı $(O R)=5.289$, \%95 güven aralığı $(C l)$ 1.680-16.651, $\mathrm{p}=0.004)$, artmış $\mathrm{LDH}(\mathrm{OR}=8.521,95 \% \mathrm{Cl}: 2.445-29.702$, p:0.001), ferritin $(\mathrm{OR}=7.436,95 \% \mathrm{Cl}: 2.171-25.468, \mathrm{p}: 0.001)$, D-dimer $(\mathrm{OR}=10.076,95 \%$ $\mathrm{Cl}: 2.758-36.813, p<0.001), C K-M B(O R=5.916,95 \%$ Cl:1.833-19.089, p:0.003) ve troponin seviyesi (OR=9.201, 95\% Cl:11.886-44.888, p:0.006) şiddetli COVID-19 için risk faktörleri olarak tanımlandı.

Sonuç: Ciddi COVID-19 için olası risk faktörlerini incelediğimiz bu çalışmada 65 yaş üstü, yükselmiş LDH, ferritin, D-dimer, CK-MB ve troponin düzeylerinin bağımsız risk faktörleri olduğunu bulduk. Klinisyenler, COVID-19 hastalarının tedavisi sırasında ciddi hastalığa ilerleme için bu potansiyel risk faktörlerini dikkate almalıdır.

Anahtar Kelimeler: COVID-19, pandemi, risk faktörü, şiddetli hastalık

Corresponding (İletişim): Fatma Çölkesen, M.D., Konya Numune Hospital, Department of Infectious Diseases and Clinical Microbiology, Konya, Turkey

E-mail (E-posta): fatma.derin@hotmail.com

Received (Geliş Tarihi): 16.10.2021 Accepted (Kabul Tarihi): 01.01 .2022 


\section{INTRODUCTION}

Coronavirus disease 2019 (COVID-19) is caused by severe acute respiratory syndrome coronavirus 2 (SARS-CoV-2) first recorded in December 2019 in Wuhan, China; the virus then rapidly spread throughout the world. ${ }^{[1]}$ The disease is highly contagious, and its primary clinical symptoms are fever, dry cough, fatigue, myalgia, and shortness of breath. While COVID-19 often presents with only upper respiratory tract symptoms, it may also manifest itself through a broad spectrum of symptoms, such as mild pneumonia, severe pneumonia, acute respiratory failure, and multiple organ damage. ${ }^{[2]}$ In a large cohort study conducted in China, the clinical status of the cases was evaluated as $81 \%$ mild, $14 \%$ severe, and $5 \%$ critical, and the overall case fatality rate (CFR) was reported to be $2.3 \% .{ }^{[3]}$ In most patients, the disease is mild and even asymptomatic, usually resolving spontaneously without the need for hospitalization. Although severe cases are rare, they are difficult to treat, and the mortality rate is high. ${ }^{[4]}$ Identifying risk factors for COVID-19 progression is crucial to help diagnose severe cases early and improve prognosis. This study aimed to determine the characteristics and risk factors associated with severe illness in COVID-19. The results of this research will help in the early detection of patients at risk of developing severe illness and improve the outcomes of these patients.

\section{MATERIAL AND METHOD}

\section{Study Setting}

The retrospective cross-sectional study was conducted in the Health Sciences University Konya Training and Research Hospital, a 1200-bed tertiary hospital located in an area with a high prevalence of COVID-19 and accepted as a reference center for COVID-19 care. Patients over 18 years of age hospitalized in the Infectious Diseases Clinic and General Intensive Care Unit (ICU) of our hospital between March and May 2020 were included in the study.

\section{Study Design}

The study sample comprised a total of 186 adult patients (97 female) hospitalized with a laboratory-confirmed (RNA SARS-CoV-2 detected by molecular method) diagnosis of COVID-19 (World Health Organization confirmed case definition). Patients were excluded from the study if they were aged $<18$ years, were pregnant, had any hematological disease, had a history of thromboembolic events, or were using anticoagulant or antiaggregant treatments for any reason. According to the National Institutes of Health $(\mathrm{NIH})$ COVID-19 Treatment Guidelines, patients with COVID-19 were categorized into groups: Mild illness defines those individuals who have any of the various signs and symptoms of COVID-19 (e.g., fever, cough, sore throat, malaise, headache, muscle pain, nausea, vomiting, diarrhea, loss of taste and smell) but who do not have shortness of breath, dyspnea, or abnormal chest imaging; moderate illness defines those individuals who show evidence of lower respiratory disease during clinical assessment or imaging and who have an oxygen saturation $\left(\mathrm{SpO}_{2}\right) \geq 94 \%$ on room air at sea level; and severe illness define those individuals who have $\mathrm{SpO}_{2}<94 \%$ on room air at sea level, a ratio of arterial partial pressure of oxygen to fraction of inspired oxygen $\left(\mathrm{PaO}_{2} / \mathrm{FiO}_{2}\right)<300 \mathrm{~mm} \mathrm{Hg}$, respiratory frequency $>30$ breaths/min, or lung infiltrates $>50 \% .^{[5]}$ In accordance with this classification, 43 patients were included in the severe COVID-19 group and 143 in the non-severe (mild or moderate) group. The possible risk factors evaluated were age, gender, comorbidities, smoking history, symptoms, and laboratory parameters during hospitalization. Among the comorbidities considered were diabetes mellitus (DM), malignancy, chronic lung disease, hypertension (HT), and cardiovascular (CV) disease. The symptoms analyzed were fever, sore throat, headache, dizziness, weakness, myalgia, cough, shortness of breath, chest pain, palpitations, anorexia, abdominal pain, diarrhea, decreased sense of smell and taste, and nasal congestion. The laboratory parameters examined during hospitalization included neutrophil count, lymphocyte count, platelet count, creatinine, alanine aminotransferase (ALT), aspartate aminotransferase (AST), lactate dehydrogenase (LDH), ferritin, C-reactive protein $(C R P)$, erythrocyte sedimentation rate (ESR), D-dimer, troponin, and creatine kinase myocardial band (CK-MB). Comparisons were made between the severe and nonsevere COVID-19 patient groups with respect to age, gender, smoking history, comorbidities, symptoms, and laboratory parameters.

\section{Ethical Approval}

Approval for the study was granted by the Local Ethics Committee of the Health Sciences University Konya Training and Research Hospital (Decision no: 08.05.2020/38-07). In addition, permission was obtained from the Ministry of Health on 05/01/2020 (Application no: 2020-04-30T14_23_49). The study was conducted in accordance with the principles of the Declaration of Helsinki 2013.

\section{Statistical Analysis}

Data obtained in the study were analyzed statistically using SPSS V22.0 software (IBM Corp., Armonk, NY, USA). Continuous variables were presented as mean \pm standard deviation (SD) values and categorical variables as number (n) and percentage (\%). In the comparisons between the severe and non-severe COVID-19 patients, the independent samples t-test was applied to evaluate continuous data and the chi-square test to evaluate categorical data. Univariate and multivariate logistic regression analyses were performed to identify risk factors for severe COVID-19. All variables with a $p$ value $<0.1$ on univariate analysis were entered into forward, stepwise multivariate logistic regression analysis. A value of $<0.05$ was considered statistically significant. 


\section{RESULTS}

According to the inclusion criteria (Figure 1), 186 patients hospitalized for laboratory-confirmed COVID-19 were included, and 97 (52.2\%) were female. The severe COVID-19 group included 43 (23.1\%) patients, and the non-severe COVID-19 group included 143 (76.9\%) patients. The patient outcomes were recorded as recovery in 169 (90.9\%) and death in 17 (9.1\%). Comorbidities of the patients were recorded as 59 (31.7\%) with $\mathrm{HT}, 19$ (10.2\%) with CV disease, $42(22.6 \%)$ with DM, 18 (9.7\%) with chronic lung disease, and $3(1.6 \%)$ with malignancy. The three most common symptoms were cough (63.4\%), weakness $(55.9 \%)$, and anorexia (50.5\%). Other symptoms were fever $(37.6 \%)$, sore throat $(34.9 \%)$, dyspnea (29\%), headache $(25.3 \%)$, myalgia (16.1\%), nasal stuffiness (15.6\%), loss of smell $(14.5 \%)$, palpitations (12.9\%), loss of taste $(12.4 \%)$, dizziness $(10.8 \%)$, diarrhea $(9.7 \%)$, chest pain $(8.1 \%)$, and abdominal pain (3.8\%). In the examination of the antiviral and antibacterial treatments administered to patients for COVID-19, all patients received hydroxychloroquine and azithromycin, 155 (83.3\%) received oseltamivir, 64 (34.4\%) received favipiravir, and 8 (4.3\%) received lopinavir/ritonavir. The demographic data and clinical characteristics of all patients with COVID-19 are summarized in Table $\mathbf{1 .}$

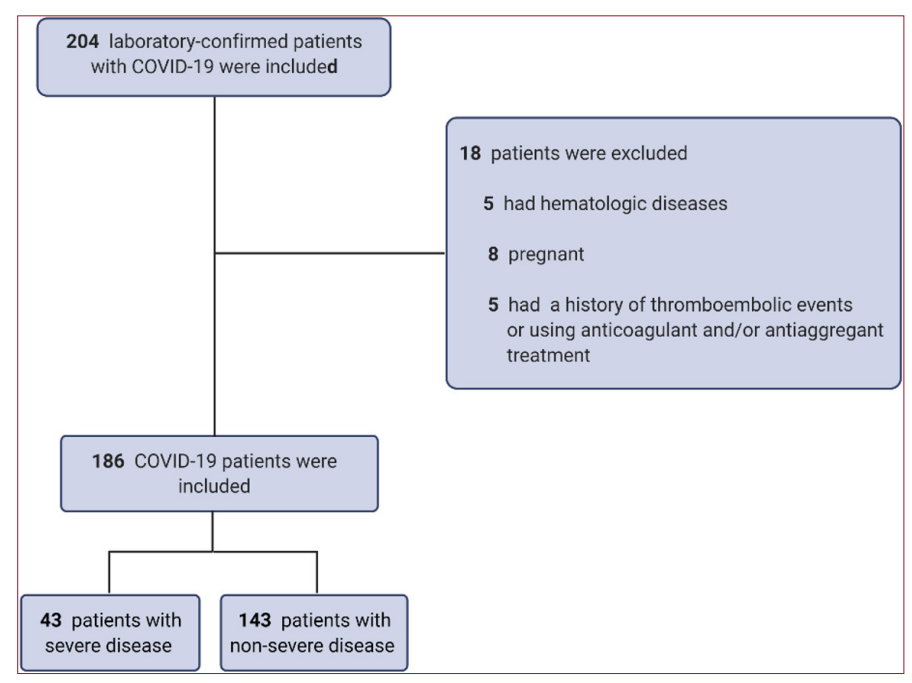

Figure 1 . The study population.

No significant difference was determined between the severe and non-severe COVID-19 groups with respect to gender $(p=0.882)$. When the two groups were compared in terms of age, the mean age of the severe patients was significantly higher than that of the non-severe patients $(p=0.001)$. When the hemogram parameters were compared, the neutrophil count was considerably higher in the severe group than in the non-severe group $(p=0.006)$. Lymphocyte and platelet counts were significantly lower in the severe versus nonsevere group ( $p<0.001$ and $p=0.031$, respectively). There was no significant difference between the two groups in terms of creatinine $(p=0.184)$. The ALT, AST, and LDH levels were
Table 1. Demographics and clinical characteristics of patients with COVID-19 $(n=186)$

\begin{tabular}{|c|c|}
\hline Characteristics & n (\%) \\
\hline \multicolumn{2}{|l|}{ Sex } \\
\hline Male & $89(47.8)$ \\
\hline Female & $97(52.2)$ \\
\hline \multicolumn{2}{|l|}{ Disease severity } \\
\hline Severe & $43(23.1)$ \\
\hline Non-severe & $143(76.9)$ \\
\hline \multicolumn{2}{|l|}{ Outcome } \\
\hline Healing & 169 (90.9) \\
\hline Exitus & $17(9.1)$ \\
\hline \multicolumn{2}{|l|}{ Comorbidity } \\
\hline Malignancy & $3(1.6)$ \\
\hline Chronic pulmonary disease & $18(9.7)$ \\
\hline Cardiovascular disease & $19(10.2)$ \\
\hline Hypertension & $59(31.7)$ \\
\hline Diabetes mellitus & $42(22.6)$ \\
\hline \multicolumn{2}{|l|}{ Symptoms at admission } \\
\hline Fever & 70 (37.6) \\
\hline Sore throat & 65 (34.9) \\
\hline Headache & $47(25.3)$ \\
\hline Dizziness & $20(10.8)$ \\
\hline Weakness & $104(55.9)$ \\
\hline Myalgia & $30(16.1)$ \\
\hline Cough & $118(63.4)$ \\
\hline Dyspnea & $54(29.0)$ \\
\hline Chest pain & $15(8.1)$ \\
\hline Palpitation & $24(12.9)$ \\
\hline Anorexia & $94(50.5)$ \\
\hline Abdominal pain & $7(3.8)$ \\
\hline Diarrhea & $18(9.7)$ \\
\hline Loss of smell & $27(14.5)$ \\
\hline Loss of taste & $23(12.4)$ \\
\hline Nasal stuffiness & $29(15.6)$ \\
\hline \multicolumn{2}{|l|}{ Treatment } \\
\hline Hydroxychloroquine & $186(100)$ \\
\hline Favipiravir & $64(34.4)$ \\
\hline Lopinavir/ritonavir & $8(4.3)$ \\
\hline Oseltamivir & $155(83.3)$ \\
\hline Azytromicin & $186(100)$ \\
\hline
\end{tabular}

significantly higher in the severe group $(p=0.040, p=0.005$, and $p=0.038$, respectively). The ferritin level was determined to be significantly higher in the severe group $(p=0.008)$. No significant difference was observed between the two groups in terms of ESR ( $p=0.255)$. CRP was found to be significantly higher in the severe group $(p<0.001)$. There was no significant difference between the two groups in terms of CK-MB ( $p=0.197)$. Troponin and D-dimer were significantly higher in the severe group than in the non-severe group $(p=0.029$ and $p=0.002$, respectively). The demographic data and laboratory parameters of the severe and non-severe patients with COVID-19 are summarized in Table 2. 


\begin{tabular}{|c|c|c|c|}
\hline Characteristics (n, \%/mean \pm SD) & $\begin{array}{c}\text { Non-severe } \\
n=143\end{array}$ & $\begin{array}{c}\text { Severe } \\
n=43\end{array}$ & $P$ value \\
\hline \multicolumn{4}{|l|}{ Demographics } \\
\hline Sex (male) & $68(47.6)$ & $21(48.8)$ & 0.882 \\
\hline \multicolumn{4}{|l|}{ Laboratory parameters } \\
\hline Neutrophils $\left(1800-6980 / \mathrm{mm}^{3}\right)$ & $3929 \pm 1924$ & $5732 \pm 3926$ & 0.006 \\
\hline Platelets (150000-450000/mm³) & $214000 \pm 69953$ & $186814 \pm 77689$ & 0.031 \\
\hline Creatinine (0.84-1.25 mg/dl) & $0.9 \pm 0.5$ & $1.2 \pm 1.6$ & 0.184 \\
\hline Alanine aminotransferase (0-50 U/L) & $23 \pm 16$ & $29 \pm 21$ & 0.04 \\
\hline Aspartate aminotransferase (0-50 U/L) & $29 \pm 15$ & $40 \pm 24$ & 0.005 \\
\hline Lactate dehydrogenase $(0-248 \mathrm{U} / \mathrm{L})$ & $273 \pm 230$ & $352 \pm 153$ & 0.038 \\
\hline Creatine kinase $-\mathrm{MB}(0-3.6 \mathrm{U} / \mathrm{L})$ & $16 \pm 8$ & $13 \pm 9$ & 0.197 \\
\hline Troponin $(0-60 \mathrm{mg} / \mathrm{L})$ & $7 \pm 17$ & $41 \pm 94$ & 0.029 \\
\hline
\end{tabular}

\section{Risk Factors for Severe COVID-19}

The results of univariate and multivariate logistic regression analyses associated with severe COVID-19 are shown in Table 3. In univariate regression analysis, risk factors for severe COVID-19 were found to be age $>65$ years and the presence of chronic pulmonary disease, DM, decreased lymphocyte count, and elevated levels of AST, LDH, ferritin, CRP, ESR, D-dimer, CK-MB, and troponin. All the variables with $\mathrm{p}$-values $<0.1$ in univariate analysis were entered into the forward step-wise multivariate logistic regression analysis. As a result of the multivariate logistic regression analysis, the risk factors for severe COVID-19 were determined to be age $>65$ years (odds ratio $(O R)=5.289,95 \%$ confidence interval $(\mathrm{Cl}) 1.680-16.651, \mathrm{p}=0.004)$, elevated levels of $\mathrm{LDH}(\mathrm{OR}=8.521,95 \% \mathrm{Cl} 2.445-29.702, \mathrm{p}=0.001)$, ferritin $(\mathrm{OR}=7.436,95 \% \mathrm{Cl} 2.171-25.468, \mathrm{p}=0.001)$, $\mathrm{D}$-dimer $(\mathrm{OR}=10.076,95 \% \mathrm{Cl} 2.758-36.813, \quad \mathrm{p}<0.001), \quad \mathrm{CK}-\mathrm{MB}$ $(\mathrm{OR}=5.916,95 \% \mathrm{Cl} 1.833-19.089, \mathrm{p}=0.003)$, and troponin $(\mathrm{OR}=9.201,95 \% \mathrm{Cl} 11.886-44.888, \mathrm{p}=0.006$; Table 3$)$.

\section{Table 3. Logistic regression analysis results of risk factors for severe COVID-19 ( $n=186)$}

\begin{tabular}{|c|c|c|c|c|c|c|}
\hline \multirow[b]{2}{*}{ Variables } & \multicolumn{3}{|c|}{ Univariate Analysis } & \multicolumn{3}{|c|}{ Multivariate Analysis } \\
\hline & OR & $95 \% \mathrm{Cl}$ & $\mathbf{p}$ & OR & $95 \% \mathrm{Cl}$ & $\mathbf{p}$ \\
\hline Gender (male vs. female) & 1.053 & $0.532-2.082$ & 0.882 & & & \\
\hline Age $>65 y$ & 3.441 & $1.697-6.978$ & 0.001 & 5.289 & $1.680-16.651$ & 0.004 \\
\hline Smoking & 1.231 & $0.371-4.082$ & 0.734 & & & \\
\hline Chronic pulmonary disease & 3.040 & $1.117-8.276$ & 0.030 & 3.220 & $0.509-20.388$ & 0.214 \\
\hline Diabetes mellitus & 2.546 & $1.206-5.373$ & 0.014 & 2.136 & $0.642-7.108$ & 0.216 \\
\hline Cardiovascular disease & 1.814 & $0.642-3.698$ & 0.122 & & & \\
\hline Hypertension & 1.348 & $0.576-4.154$ & 0.461 & & & \\
\hline Lymphocyte count decreased & 3.754 & $1.845-7.640$ & $<0.001$ & 1.388 & $0.461-4.177$ & 0.560 \\
\hline Creatinine increased & 2.560 & $1.060-6.187$ & 0.037 & & & \\
\hline Alanine aminotransferase increased & 1.436 & $0.476-4.333$ & 0.520 & & & \\
\hline Aspartate aminotransferase increased & 3.308 & $1.316-8.317$ & 0.011 & 0.599 & $0.118-3.045$ & 0.537 \\
\hline Lactate dehydrogenase increased & 4.389 & $2.048-9.408$ & $<0.001$ & 8.521 & $2.445-29.702$ & 0.001 \\
\hline Ferritin increased & 8.727 & $3.868-19.689$ & $<0.001$ & 7.436 & $2.171-25.468$ & 0.001 \\
\hline$C$ reactive protein increased & 6.445 & $2.941-14.124$ & $<0.001$ & 1.664 & $0.454-6.102$ & 0.442 \\
\hline Erythrocyte sedimentation rate increased & 2.961 & $1.468-5.974$ & 0.002 & 2.123 & $0.714-6.312$ & 0.176 \\
\hline D-dimer & 7.200 & $3.133-16.544$ & $<0.001$ & 10.076 & $2.758-36.813$ & $<0.001$ \\
\hline Creatine kinase myocardial band increased & 3.192 & $1.537-6.629$ & 0.002 & 5.916 & $1.833-19.089$ & 0.003 \\
\hline Troponin increased & 11.023 & $3.908-31.090$ & $<0.001$ & 9.201 & $1.886-44.888$ & 0.006 \\
\hline
\end{tabular}




\section{DISCUSSION}

The results of the current study demonstrated that the clinical features of age $>65$ years and elevated levels of $L D H$, ferritin, D-dimer, CK-MB, and troponin according to laboratory tests were associated with severe COVID-19. The clinical spectrum of COVID-19 may vary from asymptomatic to severe; respiratory failure requiring mechanical ventilation, sepsis, septic shock, metabolic acidosis, coagulation disorder, and multiorgan failure may be seen. ${ }^{[6]}$ It is critical to analyze the clinical features of COVID-19 in different regions and identify risk factors to reduce severe and critical illness incidence at an early stage.

In light of data from many countries, the elderly population is known to be at a higher risk of severe consequences of COVID-19 and has the most significant risk of death. ${ }^{[7]}$ In a series of multivariable-adjusted analyses based on COVID-19 patient cohorts, more severe illness cases have been associated with advanced age. ${ }^{[8-10]}$ Physiological changes that develop with aging, such as the disruption of the barrier systems in the skin, the respiratory system, and the gastrointestinal system, and a decrease in mucociliary clearance create a predisposition to infections. The age-related weakening of the immune systems of elderly patients leads to more severe infections than that in younger individuals. ${ }^{[1]}$ Elderly patients have a higher prevalence of frailty and comorbidity, which reduces their functional reserve. Furthermore, their capacity and flexibility against diseases and infections are decreased. ${ }^{[12]}$ The results of this study allowed the conclusion that being over the age of 65 years increased the risk of serious COVID-19 5.2-fold.

Previous studies have shown that a high LDH level is a risk factor for mild patients to progress toward critical illness. ${ }^{[13]}$ According to a meta-analysis of 3117 hospitalized COVID-19 patients, the mean LDH value of severe patients was 1.54fold higher than in non-severe cases. ${ }^{[14]}$ High basal LDH levels were significantly associated with the risk of acute respiratory distress syndrome (ARDS) and mortality. ${ }^{[15]}$ According to the results of the current study, elevated LDH levels increase the risk of serious COVID-19 8.5-fold. High LDH levels in severe COVID-19 patients are thought to be associated with lung damage and tissue damage. ${ }^{[16,17]}$

Many studies have associated elevated serum ferritin levels with mortality and the development of severe consequences in COVID-19. ${ }^{[18]}$ A meta-analysis of 25 studies and 5350 patients showed that high ferritin is associated with a poor outcome and ARDS development in COVID-19 patients. ${ }^{[19]}$ Active ferritin production occurs during inflammatory diseases. Cytokineproducing macrophages, which make up most immune cells in the lung parenchyma, are thought to be responsible for serum ferritin secretion. In addition, ferritin synthesis can be induced by many inflammatory stimuli, including cytokines such as IL-6. [20] The results of the current study demonstrated that elevated ferritin levels increased the risk of serious COVID-19 7.4-fold.

A meta-analysis that included 5872 COVID-19 patients showed that higher D-dimer concentrations were associated with severe illness and death in these patients. ${ }^{[21]}$ Another study of
343 hospitalized COVID-19 patients concluded that D-dimer levels $>2.0 \mu \mathrm{g} / \mathrm{mL}$ at hospital admission were an independent predictor of in-hospital mortality. ${ }^{[22] ~ V i r a l ~ i n f e c t i o n s ~ a r e ~}$ usually accompanied by an aggressive pro-inflammatory response and an inadequate anti-inflammatory response. This can cause the dysfunction of endothelial cells, resulting in excess thrombin formation. Moreover, severe COVID-19 can increase blood viscosity and induce thrombosis via a hypoxiainducible transcription factor-dependent signaling pathway. Coagulopathy and even diffuse intravascular coagulation may develop in some patients due to sepsis. ${ }^{[22]}$ The results of the current study found that a high D-dimer level increased the risk of severe illness 10 -fold.

COVID-19 is associated with many direct or indirect cardiovascular complications, such as myocarditis, myocardial damage, arrhythmia, and venous thromboembolism. ${ }^{[23]}$ Troponin and CK-MB have been identified as biomarkers of cardiac injury. In a study examining 416 cases, the troponin level was significantly higher in COVID-19 patients who were followed up in the intensive care unit (ICU) than in those who were not. ${ }^{[24]}$ The results of multivariate logistic regression analysis determined elevated troponin levels to be an independent risk factor for critical illness. ${ }^{[25]}$ In a retrospective study conducted with 138 patients, troponin and CK-MB were significantly higher in all patients requiring ICU hospitalization, and it was suggested that CK-MB has predictive value. ${ }^{[26]}$ A meta-analysis including 4189 patients found that troponin and CK-MB were significantly increased in those with severe illness compared to those with mild illness. ${ }^{[27]}$ In the current study, it was concluded that elevated troponin increased the risk of serious COVID-19 9.2-fold, and elevated CK-MB increased the risk 5.9-fold. Different theories about the cardiac injury mechanism in COVID-19 have been proposed, and further studies are needed for clarification.

\section{Limitations}

This study had some limitations, primarily because the data of the two groups were not balanced, and the sample size of the severe group was relatively small. A second limitation was that no further examination was made to reveal the relationship between elevated laboratory parameters and related organ injury. Finally, only the values of the examined laboratory parameters on presentation were considered, and the changes in the following days were not evaluated.

\section{CONCLUSION}

In this study, which examined possible risk factors for severe COVID-19, the results showed that age $>65$ years and elevated levels of LDH, ferritin, D-dimer, CK-MB, and troponin were independent risk factors. Clinicians should consider these potential risk factors for progression to severe illness when treating COVID-19 patients. The determination of possible severe patients at early stages will influence the treatments to be applied and reduce the morbidity and mortality of these patients. 


\section{ETHICAL DECLARATIONS}

Ethics Committee Approval: Approval for the study was granted by the Local Ethics Committee of the Health Sciences University Konya Training and Research Hospital (Decision no: 08.05.2020/38-07).

Informed Consent: All patients signed the free and informed consent form.

Referee Evaluation Process: Externally peer-reviewed. Conflict of Interest Statement: The authors have no conflicts of interest to declare.

Financial Disclosure: The authors declared that this study has received no financial support.

Author Contributions: All of the authors declare that they have all participated in the design, execution, and analysis of the paper, and that they have approved the final version.

\section{REFERENCES}

1. Lai CC, Wang CY, Wang YH, et al. Global epidemiology of coronavirus disease 2019 (COVID19): disease incidence, daily cumulative index, mortality, and their association with country health care resources and economic status. Int J Antimicrob Agents 2020;105946.

2. Wu Z, McGoogan JM. Characteristics of and important lessons from the Coronavirus Disease 2019 (COVID-19) outbreak in China:summary of a Report of 72314 cases from the Chinese Center for Disease Control and Prevention. JAMA 2020;323:1239-42.

3. Cai H, Chen Y, Chen Z, et al. Handbook of COVID-19 prevention and treatment. 1st ed. Liang T, editor. China:The First Affiliated Hospital, Zhejiang University School of Medicine 2020. p. 1-84.

4. Ou M, Zhu J, Ji P, et al. Risk factors of severe cases with COVID-19:a metaanalysis. Epidemiol Infect 2020;148:e175

5. National Institutes of Health. Coronavirus Disease 2019 (COVID-19) Treatment Guidelines. Available from: https:// covid19treatmentguidelines.nih.gov

6. Huang $C$, Wang $Y, \operatorname{Li} X$, et al. Clinical features of patients infected with 2019 novel coronavirus in Wuhan, China. Lancet 2020;395(10223):497506.

7. İlgili Ö, Kutsal YG. Impact Of Covid-19 Among The Elderly Population. Turk J Geriatr 2020;23(4):419-23.

8. Zhou F, Yu T, Du R, et al. Clinical course and risk factors for mortality of adult inpatients with COVID-19 in Wuhan, China:a retrospective cohort study. Lancet 2020;395(10229):1054-62.

9. Zhang JJ, Cao YY, Tan G, et al. Clinical, radiological, and laboratory characteristics and risk factors for severity and mortality of 289 hospitalized COVID-19 patients. Allergy 2021;76:533-50.

10. Ebinger JE, Achamallah N, Ji H, et al. Pre-existing traits associated with Covid-19 illness severity. PLoS One 2020;15(7):e0236240.

11. Castle SC, Uyemura K, Fulop T, Makinodan T. Host resistance and immune responses in advanced age. Clin Geriatr Med 2007;23(3):463-79.

12. Cesari M, Araujo de Carvalho I, Amuthavalli Thiyagarajan J, et al. Evidence for the domains supporting the construct of intrinsic capacity. J Gerontol Series A 2018;73(12:1653-60.

13. Phan LT, Nguyen TV, Luong QC, et al. Importation and human-tohuman transmission of a novel coronavirus in Vietnam. New Eng J Med 2020;382:872-4.

14. Bao J, Li C, Zhang K, Kang H, Chen W, Gu B. Comparative analysis of laboratory indexes of severe and non-severe patients infected with COVID-19. Clin Chim Acta 2020;509:180-94.

15. Wu C, Chen X, Cai Y, et al. Risk factors associated with acute respiratory distress syndrome and death in patients with coronavirus disease 2019 pneumonia in Wuhan. China. JAMA Intern Med 2020;180(7):934-43.
16. Li X, Xu S, Yu M, et al. Risk factors for severity and mortality in adult COVID-19 inpatients in Wuhan. Journal of Allergy and Clinical Immunology 2020;146(1):110-8.

17. Han $\mathrm{Y}$, Zhang $\mathrm{H}, \mathrm{Mu} \mathrm{S}$, et al. Lactate dehydrogenase, an independent risk factor of severe COVID-19 patients:a retrospective and observational study. Aging (Albany NY) 2020;12(12):11245.

18. Gao YD, Ding $M$, Dong $X$, et al. Risk factors for severe and critically ill COVID-19 patients:a review. Allergy 2021;76(2):428-55.

19. Huang I, Pranata R, Lim MA, Oehadian A, Alisjahbana B. C-reactive protein, procalcitonin, D-dimer, and ferritin in severe coronavirus disease-2019:a meta-analysis. Ther Adv Respir Dis 2020;14:1753466620937175.

20. Rosário C, Zandman-Goddard G, Meyron-Holtz EG, D'Cruz DP, Shoenfeld Y. The Hyperferritinemic Syndrome:macrophage activation syndrome, Still's disease, septic shock and catastrophic antiphospholipid syndrome. BMC Med 2013;11:185.

21. Lala A, Johnson KW, Januzzi JL, et al. Prevalence and impact of myocardial injury in patients hospitalized with COVID-19 infection. J Am Coll Cardiol 2020;76(5):533-46.

22. Zhang L, Yan X, Fan Q, et al. D-dimer levels on admission to predict in-hospital mortality in patients with Covid-19. J Thromb Haemost 2020;18(6):1324-9.

23. Aktoz M, Altay $H$, Aslanger $E$, et al. Turk kardiyoloji derneği uzlaşı raporu:COVID-19 pandemisi ve kardiyovaskuler hastalıklar konusunda bilinmesi gerekenler. Turk Kardiyol Dern Ars 2020;48Suppl 1:1-87.

24. Zeng JH, Wu WB, Qu JX, et al. Cardiac manifestations of COVID-19 in Shenzhen, China. Infection 2020;48(6):861-70.

25. Chen C, Chen C, Yan JT, Zhou N, Zhao JP, Wang DW. Analysis of myocardial injury in patients with COVID-19 and association between concomitant cardiovascular diseases and severity of COVID-19. Zhonghua Xin Xue Guan Bing Za Zhi 2020;48(7):567-71.

26. Wang D, Hu B, Hu C, et al. Clinical characteristics of 138 hospitalized patients with 2019 novel coronavirus-infected pneumonia in Wuhan, China. JAMA 2020;323:1061-9.

27. Li JW, Han TW, Woodward M, et al. The impact of 2019 novel coronavirus on heart injury:a systematic review and meta-analysis. Prog Cardiovasc Dis 2020;63(4):518-24. 